\title{
Growth and survival of Octopus vulgaris (Cuvier 1797) paralarvae fed on three Artemia-based diets complemented with frozen fish flakes, crushed zooplankton and marine microalgae
}

\author{
LIDIA FUENTES ${ }^{1}$, FRANCISCO JAVIER SÁNCHEZ ${ }^{1}$, MARÍA JESÚS LAGO ${ }^{1}$, \\ JOSÉ IGLESIAS ${ }^{1}$, GEMA PAZOS ${ }^{2}$ and FÁTIMA LINARES ${ }^{2}$ \\ ${ }^{1}$ Instituto Español de Oceanografía, Centro Oceanográfico de Vigo, Subida a Radio Faro, 50, 36390 Vigo. \\ Pontevedra, Spain. E-mail: lidia.fuentes@vi.ieo.es \\ ${ }^{2}$ Centro de Investigacións Mariñas, Xunta de Galicia, Pedras de Corón, s/n Apdo. 13, \\ 36620 Vilanova de Arousa, Pontevedra, Spain.
}

\begin{abstract}
SUMMARY: During one month, paralarvae of common octopus (Octopus vulgaris) were fed 3 different diets: (1) Artemia sp. enriched with Isochrysis galbana (AI) complemented with sand eel (Hyperoplus lanceolatus) flakes (AH); (2) Artemia sp. enriched with crushed marine zooplankton (AZ); and (3) Artemia sp. cultured with Isochrysis galbana and further enriched with the microalga Nannochloropsis sp. (AN). The highest dry weight $(1.6179 \pm 0.3861 \mathrm{mg}$ ) was registered with the AN diet and the best average survival $(67.0 \%)$ with the AZ diet. Considering the highest dry weight obtained, the moderate high survival and the fact that with this diet it was possible to attain the adult stage, the AN diet was the most appropriate. The reasons for the best result in growth observed with AN are discussed as: (1) the combination of docosahexaenoic acid (DHA) provided by Isochrysis galbana and the high eicosapentaenoic acid (EPA) content present in Nannochloropsis sp.; (2) the fact that the higher protein/lipid ratio of this diet improves the final dry weight of the paralarvae; and (3) the fact that Nannochloropsis sp. could inhibit the harmful microflora growth in the rearing tank. Regarding nutritional aspects, DHA content per se is not the only determinant factor for growth and survival of $O$. vulgaris paralarvae, but the presence of a high protein/lipid ratio and a high phospholipid content in the diet could possibly explain the better quality and strength of the paralarvae.
\end{abstract}

Keywords: Octopus vulgaris, paralarvae rearing, growth, survival, protein/lipid, DHA, EPA.

RESUMEN: CRECIMIENTO Y SUPERVIVENCIA DE PARALARVAS DE OCTOPUS VULGARIS (CUVIER I797) ALIMENTADAS CON TRES DIETAS BASADAS EN ARTEMIA COMPLEMENTADAS CON LAMINILLAS DE PESCADO CONGELADO, ZOOPLANCTON TRITURADO Y MICROALGAS MARINAS. - Paralarvas de pulpo común (Octopus vulgaris) fueron alimentadas, durante un mes, con tres dietas diferentes: (1) Artemia sp. enriquecida con Isochrysis galbana (AI) complementada con laminillas de lanzón (Hyperoplus lanceolatus) congelado (AH); (2) Artemia sp. enriquecida con zooplancton marino congelado (AZ) y (3) Artemia sp. cultivada con Isochrysis galbana y posteriormente enriquecida con la microalga Nannochloropsis sp. (AN). El peso seco más alto $(1.6179 \pm 0.3861 \mathrm{mg})$ fue registrado con la dieta AN y la mejor supervivencia media (67.0\%) con la dieta AZ. La dieta AN fue la más apropiada teniendo en cuenta el peso seco más alto, la supervivencia moderadamente elevada y el hecho de que con esta dieta fue posible alcanzar el estadio adulto. Se discuten las causas del mejor resultado de crecimiento observado con AN: (1) la combinación de DHA proporcionada por Isochrysis galbana y el alto contenido en EPA presente en Nannochloropsis sp.; (2) el ratio proteínas/lípidos más elevado de esta dieta puede mejorar el peso seco final de las paralarvas; y (3) es posible que Nannochloropsis sp. inhiba el crecimiento de microflora dañina en el tanque de cultivo. Con respecto a los aspectos nutricionales, el contenido en DHA per se no es el único factor determinante para el crecimiento y supervivencia de paralarvas de $O$. vulgaris, pero la presencia de un ratio proteínas/lípidos alto y un elevado contenido en fosfolípidos en la dieta podría determinar la mejor calidad y fortaleza de las paralarvas.

Palabras clave: Octopus vulgaris, cultivo de paralarvas, crecimiento, supervivencia, proteínas/lípidos, DHA, EPA. 


\section{INTRODUCTION}

The complete commercial rearing process of the common octopus (Octopus vulgaris Cuvier, 1797) has not been successfully achieved due to the high paralarvae mortality in the first weeks of life (Iglesias et al., 2007; Villanueva and Norman, 2008). Itami et al. (1963), Villanueva (1994, 1995) and Villanueva et al. $(1995,1996)$ were pioneers in obtaining benthic octopuses at 60 days old, using live crustacean zoeae as the main food source. Also during experimental trials, some authors have successfully reared a small number of paralarvae up to juveniles and even subadults (Rodríguez and Carrasco, 1999; Moxica et al., 2002; Carrasco et al., 2005), using an Artemia-based diet complemented with crab zoeae. However, all of these experiences were economically unviable. The life cycle of $O$. vulgaris under captivity was completed for the first time in 2001 (Iglesias et al., 2004) using the same diet. Nevertheless, all these achievements have always been laboratory experiments that are difficult to reproduce on a commercial scale.

At an international workshop held in Vigo (Spain) in November 2005, experts in octopus rearing mentioned nutrition as the determinant factor in larval mortality and recommended the search for new preys and the formulation of new enrichment diets for Artemia sp. (Iglesias et al., 2007).

Some authors have studied the biochemical composition of paralarvae and their live preys. Navarro and Villanueva $(2000,2003)$ reported a deficiency in polyunsaturated fatty acids (PUFA) of the diets utilized (usually enriched Artemia) as a cause of the low growth and survival in cultivation. They indicated the importance of the docosahexaenoic acid (DHA) in the composition of the juveniles of octopus, sepia and squid. Okumura et al. (2005) increased the proportion of PUFA in the diet using Artemia supplemented with flakes of Ammodytes personatus.

Another important nutritional item to be considered is the amino acid (AA) composition of the preys. Villanueva et al. (2004) found that lysine, arginine and leucine represented about half of the total essential amino acids (EAA) in paralarvae. More recently, Villanueva and Bustamante (2006) also studied the possible importance of essential elements such as copper in the diet, and Seixas et al. (2010) indicate Isochrysis galbana and Rhodomonas lens as the best microalgae combination to enrich Artemia used for O. vulgaris paralarvae.

Since the use of zoeae is not possible for largescale cultivation, new methods are required to enable octopus paralarvae to be reared commercially. The objective of this work was to analyze growth and survival of octopus paralarvae using 3 Artemia-based diets complemented with frozen fish flakes, crushed zooplankton and marine microalgae. In addition, it also tried to evaluate the viability of these 3 diets at industrial level.

\section{MATERIALS AND METHODS}

\section{Paralarvae rearing}

Octopus paralarvae were obtained from a broodstock maintained in the Spanish Institute of Oceanography (Vigo), in accordance with the methodology described by Moxica et al. (2001). Paralarvae from the same egg mass, obtained in April 2007, were used to carry out 3 experiments in duplicate using $1000-\mathrm{L}$ tanks with 3 different diets:

AH: Four day-old cultured Artemia sp. complemented with flakes of sand eel (Hyperoplus lanceolatus Le Sauvage, 1824).

AZ: Four-day-old Artemia sp. enriched $24 \mathrm{~h}$ with crushed wild zooplankton, collected with a $300-\mu \mathrm{m}$ plankton net on the adjacent Galician shelf.

AN: Four day-old Artemia sp. enriched for $24 \mathrm{~h}$ with Nannochloropsis sp. microalgae.

The Artemia sp. was grown for 4 days at $24^{\circ} \mathrm{C}(1.8$ $2.0 \mathrm{~mm}$ total length) in a 400-L tank with Isochrysis galbana at a concentration of $0.410^{6}$ cel. $\mathrm{mL}^{-1}$.

Paralarvae were reared in 1000-L black cylindrical tanks (diameter, $130 \mathrm{~cm}$ ), with a gentle central aeration that provided a homogeneous distribution of the paralarvae and their prey throughout the entire water column. Water was renewed daily for 3-4 h through a lateral drainage of $500 \mu \mathrm{m}$ and an inflow of $600 \mathrm{~L} \mathrm{~h}^{-1}$ of $1-\mu \mathrm{m}$-filtered seawater. Temperature was $21 \pm 1.8^{\circ} \mathrm{C}$ and salinity was $34 \pm 1$. Fluorescent tubes providing 600 Lux at the water surface were used between 06:00 and 21:00 h. An initial density of 5 ind. $\mathrm{L}^{-1}$ (5000 paralarvae per tank) was used.

Survival and growth were recorded weekly. Ten paralarvae were individually weighed on a Mettler UM3 microbalance (precision: $0.0001 \mathrm{mg}$ ) after being washed with distilled water and dried at $80^{\circ} \mathrm{C}$ for 24 h. Survival was calculated through volumetric estimations, counting the number of paralarvae in 20 two-L samples. The specific characteristics of each treatment are described below. Dissolved oxygen, nitrites and ammonium were measured daily.

1. Paralarvae reared with Artemia sp. and sliced sand eel flakes

For four days Artemia sp. ongrown with Isochrysis galbana (AI) was supplied at a density of 1 ind. $\mathrm{mL}^{-1}$. Four daily rations of sand eel flakes were also added at $09.00,12.00,15.00$ and $17.00 \mathrm{~h}$ from the first week of life onwards. The flakes, fine sheets around 2-3 mm long, were obtained by slicing a block of frozen sand eel with a knife, and were then spread over the tank surface; $2 \mathrm{~g}$ of fish flakes was provided each time. At the beginning, the flakes remained on the surface and approximately half an hour later they started to descend in the water column and were captured by the paralarvae. After the 3-4 h water renewal period, the circuit was closed and Isochrysis galbana was added at a concentration of $150000 \mathrm{cel}$. $\mathrm{mL}^{-1}$. The tank was cleaned every 2 days by siphoning the bottom. 
2. Paralarvae reared with Artemia sp. enriched with zooplankton

Artemia sp., previously grown with I. galbana was enriched for $24 \mathrm{~h}$ with crushed zooplankton and then supplied in 2 rations at a density of 1 ind. $\mathrm{mL}^{-1}$. Frozen tablets of wild zooplankton collected from Galician coastal waters (Ría de Vigo) were used. Thirty grams of zooplankton was used to enrich each million of Artemia sp.; the zooplankton tablet was crushed in an Ultraturrax ${ }^{\circledR}$ blender and filtered through a $60-\mu \mathrm{m}$ filter. The resulting solution was added to a $20-\mathrm{L}$ tank to enrich Artemia sp. for $24 \mathrm{~h}$. Phytoplankton was not added to the rearing tank.

3. Paralarvae reared with Artemia sp. enriched with Nannochloropsis sp.

Four-day-old Artemia sp. cultured with I. galbana was further enriched for $24 \mathrm{~h}$ in a 20 -L tank containing $10^{7}$ cel. $\mathrm{mL}^{-1}$ of Nannochloropsis sp. and supplied to the rearing tank at a density of 0.5 ind. $\mathrm{mL}^{-1}$ until day 20 and 0.3 ind. $\mathrm{mL}^{-1}$ until day 30 . A concentration of $1.10^{6}$ cel. $\mathrm{mL}^{-1}$ of Nannochloropsis sp. was maintained daily in the rearing tank.

\section{Biochemical analysis}

Samples for biochemical analysis of both paralarvae (30 days old) and diets were taken throughout the experimental period. They were washed with distilled water, frozen at $-80^{\circ} \mathrm{C}$ and subsequently freeze-dried. Analysis of proteins, total lipids, classes of lipids and fatty acids was carried out in triplicate. Proteins were determined by the Bradford method (1976). Total lipids were extracted with chloroform-methanol (2:1) in accordance with Blight and Dyer (1959), modified by Fernández-Reiriz et al. (1989) and were determined by gravimetry in microbalance. Lipid classes were separated by thin-layer chromatography (TLC) in accordance with Freeman and West (1966) and Bitman and Wood (1982), and were classified by densitometry. Fatty acids, after transesterification and methylation to their methylated esters using the Lepage and Roy method (1986), were analyzed by gas chromatography using a Perkin Elmer Mod. 8700 chromatograph.

\section{Statistical analysis}

The slopes of the growth equations were compared using the $t$ test; $P<0.05$. Final dry weights of the reared paralarvae of the 3 experiments were compared with ANOVA analysis following by a $t$ test of means comparison. All biochemical results of paralarvae were submitted to a one-way ANOVA with the statistical programme Minitab 15. When the test showed significance, individual means were compared using Tukey's test. Significant differences were considered when $P<0.05$. All fatty acids of the paralarvae were analyzed by a multivariate model of discriminant function, using the statistical package SPSS version 11.5. Navarro and Villanueva (2003) used this same method of discrimi-

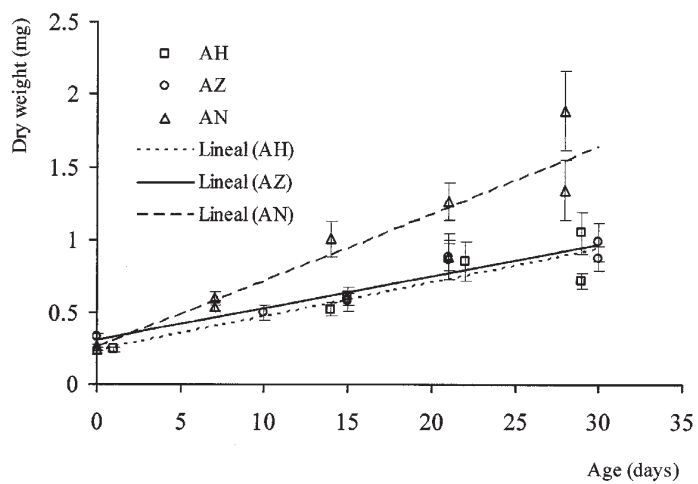

FIG. 1. - Growth in dry weight (mg) of Octopus vulgaris paralarvae fed on 3 different diets: Artemia sp. and sand eel (AH), Artemia sp. enriched with zooplankton (AZ) and Artemia sp. enriched with Nannochloropsis sp. (AN). Lines represent regression lines of each treatment.

nant analysis based only on certain fatty acids (16:0, $16: 1 \mathrm{n}-7,18: 0,18: 1 \mathrm{n}-9,18: 1 \mathrm{n}-7,20: 4 \mathrm{n}-6,20: 5 \mathrm{n}-3$, $22: 5 n-3$ and $22: 6 n-3)$ to compare paralarvae reared on different diets with wild juveniles.

\section{RESULTS}

\section{Growth and survival}

Figure 1 shows the growth curves of the $O$. vulgaris paralarvae reared for a month with 3 different diets. The highest growth was obtained with AN $(P<0.05)$, reaching a mean dry weight of $1.6179 \pm 0.3861 \mathrm{mg}$. This value was significant higher $(P<0.05)$ than those obtained with $\mathrm{AH}$ and $\mathrm{AZ}(0.8686 \pm 0.2197$ and $0.9316 \pm 0.0804 \mathrm{mg}$, respectively).

Growth was fitted to regression lines for each treatment:

$$
\begin{aligned}
& \text { AH: } \mathrm{y}=0.0237 \mathrm{x}+0.2317 ; r^{2}=0.813 \\
& \text { AZ: } \mathrm{y}=0.0222 \mathrm{x}+0.3035 ; r^{2}=0.9065 \\
& \text { AN: } \mathrm{y}=0.0461 \mathrm{x}+0.2481 ; r^{2}=0.8774
\end{aligned}
$$

Slopes were significantly different $(P<0.05)$ for paralarvae fed with AN compared with the other 2 diets; on the other hand, no differences $(P>0.05)$ were found between these 2 diets.

Mean survival was significantly higher $(P<0.05)$ in the group fed with $\mathrm{AZ}(67.0 \%)$ than in those fed with $\mathrm{AN}$ and $\mathrm{AH}$ (46.6\% and $27.2 \%$, respectively).

Although this work refers to the first month of life, rearing trials were maintained over time and paralarvae fed with Artemia sp. enriched with Nannochloropsis sp. were the only group to reach the adult stage. Data on survival at settlement and weaning process will be published in another paper (Iglesias, pers. comm.).

\section{Biochemical composition of the diets and paralarvae}

The protein, total lipid, lipid classes and fatty acid composition of diets and paralarvae is shown in Table 1. AH paralarvae showed the highest percentage 
TABLE 1. - Biochemical composition of the diets used (AI, Artemia sp. grown with Isochrysis galbana; H, Sand eel (H. lanceolatus); AZ, Artemia sp. enriched with zooplankton; AN, Artemia sp. enriched with Nannochloropsis sp.) and that of the paralarvae reared with those diets at one month of age (AH corresponds to paralarvae fed with $\mathrm{AI}$ and $\mathrm{H}$ ).

\begin{tabular}{|c|c|c|c|c|c|c|c|}
\hline & & & & & & Paralarvae & \\
\hline & $\mathrm{AI}$ & $\mathrm{H}$ & $\mathrm{AZ}$ & $\mathrm{AN}$ & $\mathrm{AH}$ & $\mathrm{AZ}$ & $\mathrm{AN}$ \\
\hline Proteins y lipids ${ }^{1}$ & & & & & & & \\
\hline Proteins & 51.17 & $54.26^{\mathrm{a}}$ & $36.52^{b}$ & $41.36^{c}$ & $47.32^{\mathrm{a}}$ & $52.29^{b}$ & $45.76^{\mathrm{a}}$ \\
\hline Lipids & 19.01 & $11.15^{\mathrm{a}}$ & $12.60^{\mathrm{b}}$ & $7.37^{c}$ & $16.85^{\mathrm{a}}$ & $12.58^{\mathrm{b}}$ & $14.71^{\mathrm{ab}}$ \\
\hline Lipid classes ${ }^{2}$ & & & & & & & \\
\hline Esters and Waxes & 0.00 & 0.00 & 0.00 & 0.00 & 2.11 & 7.68 & 5.39 \\
\hline Triglycerides & 26.75 & 5.23 & $*$ & $*$ & 1.80 & $*$ & $*$ \\
\hline Free Fatty Acids & 2.26 & 7.32 & $*$ & $*$ & 6.97 & $*$ & $*$ \\
\hline Sterols & 2.22 & 1.65 & 16.60 & 9.28 & 12.07 & 16.55 & 12.42 \\
\hline Phospholipids & 44.54 & 59.58 & 57.64 & 49.75 & 37.27 & 43.82 & 38.77 \\
\hline Fatty Acid ${ }^{3}$ & & & & & & & \\
\hline $14: 0$ & 6.21 & 4.15 & 0.84 & 0.49 & 1.51 & 0.53 & 0.70 \\
\hline $14: 1$ & 0.46 & 0.17 & 0.04 & 0.06 & 0.11 & 0.06 & 0.12 \\
\hline $15: 0$ & 0.36 & 0.05 & 0.05 & 0.04 & 0.02 & 0.08 & 0.07 \\
\hline $16: 0$ & 7.34 & 13.08 & 5.19 & 4.05 & 7.51 & 9.94 & 9.67 \\
\hline $16: 1 n-11$ & 0.02 & 0.27 & 0.22 & 0.02 & 0.12 & 0.25 & 0.16 \\
\hline $16: 1 n-9$ & 0.28 & 0.26 & 0.11 & 0.08 & $0.37^{\mathrm{a}}$ & $0.47^{\mathrm{a}}$ & $0.11^{b}$ \\
\hline $16: 1 n-7$ & 3.95 & 3.02 & 1.61 & 3.20 & 2.56 & 0.60 & 1.73 \\
\hline $16: 1 n-5$ & 0.06 & 0.17 & 0.23 & 0.02 & 0.07 & 0.27 & 0.06 \\
\hline $17: 0$ & 1.35 & 0.75 & 0.76 & 0.62 & $1.33^{\mathrm{a}}$ & $1.37^{\mathrm{a}}$ & $0.89^{b}$ \\
\hline $16: 2 n-4$ & 0.14 & 0.21 & 0.24 & 0.17 & 0.84 & 1.69 & 1.11 \\
\hline $17: 1$ & 0.34 & 0.21 & 0.38 & 0.05 & 0.80 & 0.30 & 0.14 \\
\hline $18: 0$ & 4.54 & 3.28 & 4.95 & 3.36 & $4.41^{\mathrm{a}}$ & $6.98^{b}$ & $5.63^{b}$ \\
\hline $18: 1 n-9$ & 8.78 & 2.47 & 12.09 & 4.93 & 4.63 & 5.29 & 2.82 \\
\hline $18: 1 n-7$ & 5.13 & 1.19 & 7.04 & 3.56 & 2.97 & 3.34 & 2.15 \\
\hline $16: 4$ & 0.03 & 0.06 & 0.05 & 0.02 & $0.08^{a}$ & $0.07^{\mathrm{a}}$ & $0.03^{b}$ \\
\hline $18: 2 n-6$ & 13.58 & 0.38 & 5.75 & 3.57 & 2.51 & 1.49 & 1.01 \\
\hline $18: 3 n-3$ & 8.78 & 0.23 & 4.12 & 1.98 & 0.83 & 2.57 & 0.46 \\
\hline $20: 1 n-11$ & 0.02 & 0.11 & 0.04 & 0.02 & 0.10 & 0.14 & 0.12 \\
\hline $20: 1 n-9$ & 0.24 & 0.76 & 0.34 & 0.17 & 1.06 & 1.36 & 1.02 \\
\hline $20: 1 n-7$ & 0.04 & 0.15 & 0.08 & 0.03 & $0.09^{a b}$ & $0.12^{\mathrm{a}}$ & $0.07^{\mathrm{ab}}$ \\
\hline $18: 4 n-3$ & 7.66 & 0.38 & 2.53 & 0.52 & 0.48 & 0.42 & 0.08 \\
\hline $20: 4 n-6$ (ARA) & 1.34 & 1.39 & 2.94 & 1.18 & 3.98 & 4.21 & 3.67 \\
\hline $22: 1 \mathrm{n}-11$ & 0.00 & 0.07 & 0.03 & 0.00 & 0.00 & 0.00 & 0.15 \\
\hline $22: 1 n-9$ & 0.00 & 0.06 & 0.03 & 0.00 & 0.28 & 0.36 & 0.27 \\
\hline $22: 1 n-7$ & 0.00 & 0.00 & 0.00 & 0.00 & $0.08^{\mathrm{a}}$ & $0.30^{\mathrm{b}}$ & $0.10^{\mathrm{a}}$ \\
\hline $20: 4 n-3$ & 0.41 & 0.00 & 0.13 & 0.05 & 0.17 & 0.08 & 0.06 \\
\hline $20: 5 n-3$ & 3.78 & 3.54 & 3.85 & 5.36 & 9.66 & 11.07 & 13.22 \\
\hline $22: 5 n-3$ & 0.04 & 0.30 & 0.34 & 0.02 & $0.53^{\mathrm{ab}}$ & $0.39^{\mathrm{ab}}$ & $0.78^{a}$ \\
\hline $22: 6 n-3$ (DHA) & 2.57 & 8.48 & 0.05 & 0.09 & $5.95^{\mathrm{a}}$ & $2.92^{\mathrm{b}}$ & $1.98^{\mathrm{b}}$ \\
\hline Total FA & 77.46 & 47.65 & 56.78 & 35.30 & 56.90 & 59.55 & 51.43 \\
\hline Polyunsaturated & 38.32 & 14.97 & 19.99 & 12.96 & 25.02 & 24.88 & 22.37 \\
\hline Saturated & 19.81 & 21.31 & 11.79 & 8.55 & 14.78 & 18.89 & 16.94 \\
\hline Monounsaturated & 19.33 & 8.91 & 22.25 & 12.14 & 13.22 & 12.82 & 8.97 \\
\hline$n-3$ & 23.23 & 12.94 & 11.02 & 8.02 & 17.61 & 17.43 & 16.56 \\
\hline$n-6$ & 14.92 & 1.77 & 8.69 & 4.75 & 6.49 & 5.69 & 4.67 \\
\hline$(n-3) /(n-6)$ & 1.56 & 7.30 & 1.27 & 1.69 & 2.83 & 3.06 & 3.55 \\
\hline DHA/EPA & 0.68 & 2.39 & 0.01 & 0.02 & $0.62^{\mathrm{a}}$ & $0.27^{\mathrm{b}}$ & $0.15^{\mathrm{b}}$ \\
\hline EPA/ARA & 2.82 & 2.55 & 1.31 & 4.54 & $2.43^{\mathrm{a}}$ & $2.63^{\mathrm{a}}$ & $3.60^{\mathrm{b}}$ \\
\hline
\end{tabular}

1(\% dry weight $) ;{ }^{2}(\%$ total lipids $) ;{ }^{3}$ (ng/ $\mu$ g dry weight $)$

of lipids (16.85\%; significant, see Table 1), reflecting the lipid content of Artemia sp. enriched with Isochrysis galbana, which represents $19.01 \%$ of total lipids. Protein ranged between $46 \%$ and $52 \%$ among groups, with higher content in paralarvae fed with the AZ diet (52.29\%; significant, see Table 1). The AN diet contained the highest protein/lipid ratio (5.60 vs 3.77 and 2.90 in $\mathrm{AH}$ and $\mathrm{AZ}$, respectively) and also showed the highest final dry weight (Fig. 1).

With regard to lipid classes (\% of total lipids), the AZ diet had the highest phospholipid content $(57.64 \%)$ and produced the paralarvae with the highest phospholipid value. Fatty acid content (ng $\mu \mathrm{g} \mathrm{DW}^{-1}$ ) of the paralarvae was also clearly related to the food supplied; the AH paralarvae showed the highest DHA content (5.95, significant, see Table 1) reflecting the diet composition of sand eel (8.48) and AI (2.57). The DHA/EPA ratio was also higher in paralarvae fed with $\mathrm{AH}(0.62)$ than in paralarvae fed with AZ (0.27) and AN (0.15). However, AN paralarvae showed the highest EPA/ARA (arachidoinic acid) ratio. Although EPA values were not significantly different: paralarvae fed with AN had the highest EPA value $(13.22 \mathrm{ng} / \mu \mathrm{g}$ dry weight) followed by those fed with AZ (11.07) and AH (9.66). The diets supplied followed a similar pattern in EPA content: AN, $5.36 \mathrm{ng} / \mu \mathrm{g}$ dry weight; AZ, $3.85 \mathrm{ng} /$ $\mu \mathrm{g}$ dry weigh; the diet composed of sand eel flakes, $3.54 \mathrm{ng} / \mu \mathrm{g}$ dry weight; and Artemia sp. AI grown 


\section{Canonical Discriminant Functions}

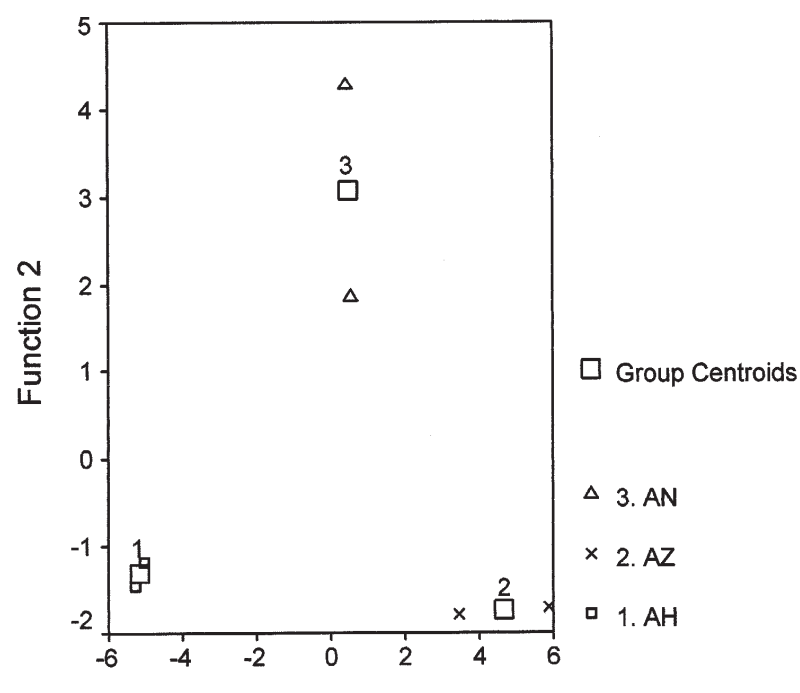

Function 1

FIG. 2. - Graphic representation of the discriminant functions generated from the fatty acids of $O$. vulgaris paralarvae fed with 3 diets: AH, Artemia sp. supplemented with H. lanceolatus; AZ, Artemia sp. enriched with zooplankton; AN, Artemia sp. enriched with Nannochloropsis sp..

and enriched with Isochrysis galbana, $3.78 \mathrm{ng} / \mu \mathrm{g}$ dry weight. The highest arachidonic acid content (20:4n-6) was recorded in paralarvae fed with AZ (4.21), with a clear relationship between the composition of this fatty acid in the food and in the paralarvae.

The discriminant analysis carried out with all fatty acids present in the one-month-old parlarvae clearly separates 3 groups, corresponding to the 3 diets tested (AH, AZ and AN). These are also well grouped with their respective replicates (Fig. 2). The 2 first discriminant functions generated by the model explain, respectively, $77.4 \%$ and $22.6 \%$ of the total variance. The values of significance of the Wilks Lambda statistic, 0.069 for function 1 and 0.096 for function 2 , indicate that these functions are significant for $P<0.1$. The structure of coefficients indicates that the first function has a high correlation with fatty acid 16:1n-9 (0.971), as well as with 20:5n-3 (0.916); for the second function a high correlation is observed with $22: 1 n-11$ (-0.993) and 22:1n-9 (0.975).

\section{DISCUSSION}

\section{Growth and survival}

The use of Artemia sp. enriched with the microalgae Nannochloropsis sp. promoted the highest mean dry weight $(1.6179 \pm 0.3861 \mathrm{mg})$ and a good survival rate $(46.6 \%)$ at day 30 . Considering that paralarvae reared with this diet were the only group that reached the adult stage (Iglesias, pers. comm.), it is concluded that this diet is the most appropriate of the 3 tested in this work. Furthermore, it is easier to obtain AN at in- dustrial level than fish flakes or crushed zooplankton, which are more complicated to prepare. Using Artemia sp. enriched with Nannochloropsis sp., Hamazaki et al. (1991) obtained a survival rate of $28.9 \%$ (23700 individuals) at the age of 25 days in a tank of $20 \mathrm{~m}^{3}$ at a mean water temperature of $26.9^{\circ} \mathrm{C}$.

Moxica et al. (2006) and Viciano et al. (2009), using also Artemia sp. enriched with Nannochloropsis, report similar values between 1.7 and $1.49 \mathrm{mg}$.

However, the results of the previously cited works using AN are lower than the successful values obtained by Iglesias et al. (2004) feeding the paralarvae on Artemia sp. and zoeae of spider crab (Maja brachydactyla). These authors obtained $31.5 \%$ survival at day 40 and a mean dry weight of $9.5 \pm 1.9 \mathrm{mg}$ at day 45 . Carrasco et al. $(2005,2006)$, using the same diet, reported survival of between $59 \%$ and $90 \%$ at day 20 , and $3.4 \%$ at day 60 , when the paralarvae had a mean dry weight of $22.02 \pm 3.8 \mathrm{mg}$. Villanueva (1995), using early hatched zoeae of Liocarcinus depuratus and Pagurus prideaux as preys, obtained a survival rate of $34.6 \%$ at day 30 , and octopuses reaching their benthic phase (day 60), with mean wet weight values of $17.45 \pm 4.73 \mathrm{mg}$.

The relatively low paralarvae weights (compared to when zoeae were used as prey) indicate that, although the minimum nutritional requirements are covered to go beyond the larval period and settlement, there are still other nutritional factors involved in growth and survival, and that further research in this field is therefore necessary in the future.

\section{Biochemical composition of diets and paralarvae}

Analyzing the biochemical composition of the 3 diets used in the present study and comparing with the paralarvae fed on zoeae of Maja brachydactyla showed that the percentage of total lipids was lower in the paralarvae fed with Artemia sp. and zoeae (10.90\% in Moxica et al., 2002) than in those reared in the present study: $16.86 \%$ for AH, $12.58 \%$ for AZ and $14.71 \%$ for AN. The low lipid content (6-9\%) of the zoeae (Andrés et al., 2010) can explain these results and agrees with the well-known fact that octopus paralarvae are lowlipid-composition organisms.

The success in the rearing experiments carried out with Artemia sp. and zoeae could be explained by the higher level of phospholipids recorded in the paralarvae $(51.73 \%$ of the total lipids (Moxica et al., 2002) in contrast with the values reported here for paralarvae fed with $\mathrm{AH}(37.27 \%)$, AZ (43.82\%) and AN (38.77\%). These values reflect the composition of the food since, in the zoeae, phospholipids represent $69.72 \%$ of the total lipids, a value that is clearly higher than in the 3 diets used here. It was also noteworthy that the highest phospholipid percentage in paralarvae (AZ) delivered the best survival, which could indicate the importance of this lipid class for $O$. vulgaris.

If we compare the DHA in this work with that of the paralarvae fed with Artemia sp. and zoeae of $M$. 
brachydactyla (Moxica et al., 2002), 2 groups can be observed: one comprises paralarvae fed on zoeae (Moxica et al., 2002) and AH paralarvae (present work), in which DHA represented 3.76 and $5.95 \mathrm{ng} /$ $\mu \mathrm{g}$ dry weight, respectively; and another is formed by the AZ and AN paralarvae (present work), with DHA values of 2.92 and $1.98 \mathrm{ng} / \mathrm{\mu g}$ dry weight, respectively. The food of the AZ and AN groups also contains lower DHA values, (0.05 and $0.09 \mathrm{ng} / \mu \mathrm{g}$ dry weight, respectively) than crab zoeae (3.40 ng/ $\mu \mathrm{g}$ dry weight) and sand eel (8.48 ng/ $\mathrm{gg})$.

However, the high DHA values recorded in H. lanceolatus and in the AH paralarvae were not associated either with greater survival or with the highest weight obtained in the present study. This could be related to the source of the DHA and other fatty acids (such as triglycerides, phospholipids or free fatty acids). In fact, copepods are nutritionally beneficial to fish larvae due to their high level of EPA and DHA, which are mainly in the form of phospholipids (Bell et al., 2003). There could also be other factors other than DHA influencing the final outcome of the culture. The very low DHA content (and therefore low DHA/EPA ratio) present in the AN diet produced, nevertheless, good results in relation to paralarval growth and survival. The same positive results using Nanochloropsis sp. were obtained in previous experiments by Hamazaki et al. (1991) and Moxica et al. (2006).

A possible explanation for the good results attained with the AN diet (Isochrysis galbana plus Nannochloropsis sp.) could be that the combination of the DHA provided by $I$. galbana and the high EPA content present in Nanochloropsis sp. could cover the basic highly unsaturated fatty acid requirements of octopus paralarvae. Also, the higher protein/lipid ratio present in the AN diet (5.60 vs 3.77 and 2.90 for $\mathrm{AH}$ and AZ, respectively) could positively affect paralarval growth. Seixas et al. (2010) reached similar conclusions and suggest that in order to sustain a good paralarvae growth, a minimum dietary protein/lipid ratio should be attained. Additionally, the high concentration of Nannochoropsis sp. in the paralarva rearing tank could produce an inhibitor effect on the growth of harmful microflora. In fact, a positive effect has been observed in mass phytoplankton cultures carried out in our facilities. Several authors have also indicated that improvement in growth or survival associated with green water is likely a result of the indirect effects that microalgae might have on the nutritional quality of the food, or on the larval physiology (Skiftesvik et al., 2003).

Results from the present experiment indicate that a high DHA content or DHA/EPA ratio in the diet does not produce higher growth or paralarvae survival, but a high protein/lipid ratio and a high phospholipid content (as source of fatty acids) can give the best quality and strength.

Results of the multivariate fatty acid analysis indicate that 2 functions determine different clusters associated with the samples or processing treatments.
Navarro and Villanueva (2003) generated 2 highly significant functions that clearly separated the 2 groups. Similarly, we found 3 differentiated groups (AH, AZ and $\mathrm{AN}$ ) related to the diets used (Fig. 2).

In the present study function 1 ( $\mathrm{x}$-axis of Figure 2 ), which explains $77.4 \%$ of the total variance and is mainly influenced by fatty acids $16: 1 n-9$ and $20: 5 n-$ 3 (EPA), could be related to some factor that affects survival, since it clusters the processing in 3 well-differentiated groups. One of them, displaced towards the right in Figure 2 (with values from 4 to 6), corresponds to the 2 replicates of the AZ processing (Artemia sp. enriched with zooplankton), which at the same time delivered the highest survival (67\%). Another intermediate group (with values of -1 to +1 ) that corresponds to the AN cultivations (Artemia sp. enriched with Nannochloropsis sp.) had an intermediate survival of $46.6 \%$. Finally, a third group displaced toward the left (with values of -4 to -6 ) and corresponding to the 2 replicates of the cultivation carried out with AH (Artemia sp. supplemented with $H$. lanceolatus) had a lower survival at one month of life $(27.2 \%)$.

On the other hand, function 2 (y-axis of Fig. 2), which represents $22.6 \%$ of the total variance of the data and is affected by fatty acids $22: 1 n-11$ and 22:1n-9, could be related to paralarval growth, since it clusters the processing into 2 well-differentiated groups. The trials carried out with AN are displaced towards the upper part of the figure with very positive values (from 2 to 4); these paralarvae are those that reached the highest dry weights $(1,6179 \pm 0.3861 \mathrm{mg})$. Meanwhile, the $\mathrm{AH}$ and $\mathrm{AZ}$ trials were grouped towards the lower part of figure 2, with moderate or low values (of -2 to -1 ), and dry weights of $0.8686 \pm 0.2197$ and $0.9316 \pm 0.0804$ $\mathrm{mg}$, respectively. Consequently, the multivariate analysis concludes that a relation exists between the fatty acid composition of paralarvae and their survival and growth at 30 days, depending on the type of prey used. Nevertheless, these assumptions must be ratified in future investigations.

\section{ACKNOWLEDGEMENTS}

This work was supported by a research agreement between the Xunta de Galicia and the Spanish Institute of Oceanography. The authors wish to thank the CIMA and IEO technicians for their invaluable help, and also Diana González for her valuable contribution in the statistical processing of the graphics. We also acknowledge the scientific revision of this work by Dr. J.C. Navarro and Dr. P. Seixas.

\section{REFERENCES}

Andrés, M., A. Estévez, C.G. Simeó and G. Rotllant. - 2010. Annual variation in the biochemical composition of newly hatched larvae of Maja brachydactyla in captivity. Aquaculture, 310: 99-105.

Bell, J.G., L.A. McEvoy, A. Estevez, R.J. Shields and J.R. Sargent. - 2003. Optimising lipid nutrition in first-feeding flat fish larvae. Aquaculture, 227: 211-220. 
Bitman, J. and D.L.Wood. - 1982. An improved copper reagent for quantitative densitometric thin-layer chromatography of lipids. J. Chromatogr., 5: 1155-1162.

Blight, E.G. and W.J. Dyer. - 1959. A rapid method of total lipid extraction and purification. Can. J. Biochem. Physiolog., 37: 911-917.

Bradford, M.M. - 1976. A rapid sensitive method for the quantisation of microgram quantities of protein utilizing the principle of protein-dye binding. Anal. Biochem., 72: 248-254.

Carrasco, J.F., C. Rodríguez, and M. Rodríguez. - 2005. Cultivo intensivo de paralarvas de pulpo (Octopus vulgaris, Cuvier) utilizando como base de la alimentación zoeas vivas de crustáceos. In: Libro de Actas. IX Congreso Nacional de Acuicultura, Octubre 2005, Sevilla, Spain, pp. 219-222.

Carrasco, J.F., J.C. Arronte and C. Rodríguez. - 2006. Paralarval rearing of the common octopus, Octopus vulgaris (Cuvier). Aquacult. Res., 37: 1601-1605.

Fernández-Reiriz, M.J., A. Pérez-Camacho, M.J. Ferreiro, J. Blanco, M. Planas, M.J. Campos and U. Labarta. - 1989. Biomass production and variation in the biochemical profile (total protein, carbohydrates, RNA, lipids and fatty acids) of seven species of marine microalgae. Aquaculture, 83: 17-37.

Freeman, C.P. and D. West. - 1966. Complete separation of lipid classes on a single thin-layer plate. J. Lipid. Res., 7: 324-327.

Hamazaki, H., K. Fukunaga, Y. Yoshida and K. Maruyama. - 1991. Effects of marine microalgae Nannochloropsis sp. on survival and growth on rearing pelagic paralarvae of Octopus vulgaris, and results of mass culture in the tank of 20 metric tons. Saibaigiken, 19: 75-84.

Iglesias, J., J.J. Otero, C. Moxica, L. Fuentes and F.J. Sánchez. 2004. The completed life cycle of the octopus (Octopus vulgaris, Cuvier) under culture conditions: paralarval rearing using Artemia and zoeae, and first data on juvenile growth up to 8 months of age. Aquacult. Int., 12: 481-487.

Iglesias, J., F.J. Sánchez, J.G.F. Bersano, J.F. Carrasco, J. Dhont, L. Fuentes, F. Linares, S. Okumura, T. van der Meeren, J.L. Muñoz, J. Roo, E.A.G. Vidal and R. Villanueva. - 2007. Rearing of Octopus vulgaris paralarvae: present status, bottlenecks and trends. Review Article. Aquaculture, 266: 1-15.

Itami, K., Y. Izawa, S. Maeda and K. Nakay. - 1963. Notes on the laboratory culture of octopus larvae. Bull. Jpn. Soc. Sci. Fish. 29(6): 514-520.

Lepage, G. and C. Roy. - 1986. Direct transesterification of all classes of lipids in a one-step reaction. Notes on methodology. J. Lipid Res., 27: 114-120.

Okumura, S., A. Kurihara, A. Iwamoto and T. Takeuchi. - 2005. Improved survival and growth in Octopus vulgaris paralarvae by feeding large type Artemia and Pacific sand eel, Ammodytes personatus. Aquaculture, 244: 144-157.

Moxica, C., J.J. Otero, J. Iglesias and F.J. Sánchez. - 2001. Comportamiento reproductor, puestas y desarrollo embrionario del pulpo Octopus vulgaris en cautividad. In: Actas del VII Congreso Nacional de Acuicultura, Las Palmas, Mayo 1999.

Moxica, C., F. Linares, J.J. Otero, J. Iglesias and F.J. Sánchez. 2002. Cultivo intensivo de paralarvas de pulpo, Octopus vul- garis Cuvier, 1797, en tanques de $9 \mathrm{~m}^{3}$. Bol. Inst. Esp. Oceanogr., 18(1-4): 31-36.

Moxica, C., L. Fuentes, J. Hernández, J. Iglesias, M.J. Lago, J.J. Otero and F.J. Sánchez. - 2006. Efecto de Nannochloropsis sp. en la supervivencia y crecimiento de paralarvas de pulpo Octopus vulgaris. IX Foro dos Recursos Mariños e da Acuicultura das Rías Galegas, October 2006, O Grove, Spain.

Navarro, J.C. and R. Villanueva. - 2000. Lipid and fatty acid composition of early stages of cephalopods: an approach to their lipid requirements. Aquaculture, 183: 161-177.

Navarro, J.C. and R. Villanueva. - 2003. The fatty acid composition of Octopus vulgaris paralarvae reared with live and inert food: deviation from their natural fatty acid profile. Aquaculture, 219: 613-631.

Seixas, P., M. Rey-Méndez, L.M.P Valente and A. Otero. - 2010. High DHA content in Artemia is ineffective to improve Octopus vulgaris paralarvae rearing. Aquaculture, 300: 156-162.

Skiftesvik, A.B., H.I. Browman and J.F. St-Pierre. - 2003. Life in green water: the effect of microalgae on the behaviour of Atlantic cod (Gadus morhua) larvae. In: H.I. Browman and A.B. Skiftesvik (eds.), 26th Annual Larval Fish Conference OS, Norway, July 22-26, 2002, pp. 97-103. Source: Big Fish Bang.

Viciano E., J. Iglesias, M.J. Lago, F.J. Sánchez, J.J. Otero and J.C. Navarro. - 2009. Fatty acid composition of polar and neutral lipid fractions of Octopus vulgaris Cuvier, 1797 paralarvae reared with enriched on-grown Artemia. Larvi'09 - Fish and Shelfish Larviculture Symposium. C.I. Hendry, G. Van Stappen, M. Wile and P. Sorgeloos (Eds). European Aquaculture Society, Special publication $\mathrm{N}^{\circ} 38$, Oostende, Belgium.

Villanueva, R. - 1994. Decapod crab zoeae as food for rearing cephalopod paralarvae. Aquaculture, 249: 143-152.

Villanueva, R. - 1995. Experimental rearing and growth of planktonic Octopus vulgaris from hatching to settlement. Can. J. Fish. and Aquat. Sci., 52: 2639-2650.

Villanueva, R. and P. Bustamante. - 2006. Composition in essential and non-essential elements of early stages of cephalopods and dietary effects on the elemental profiles of Octopus vulgaris paralarvae. Aquaculture, 261: 225-240.

Villanueva, R. and M.D. Norman. -2008. Biology of the planktonic stages of benthic octopuses. Oceanogr. Mar. Biol. Annu. Rev., 46: $105-202$

Villanueva, R., C. Nozais and S.V. Boletzky. - 1995. The planktonic life of octopuses. Nature, 377: 107.

Villanueva, R., C. Nozais and S.V. Boletzky. - 1996. Swimming behaviour and food searching in planktonic Octopus vulgaris Cuvier from hatching to settlement. J. Exp. Mar. Biol. Ecol., 208: $169-184$

Villanueva, R., J. Riba, C. Ruíz-Capillas, A.V. González and M. Baeta. - 2004. Amino acid composition of early stages of cephalopods and effect of amino acid dietary treatments on Octopus vulgaris paralarvae. Aquaculture, 242: 455-478.

Scient. ed.: P. Sanchez.

Received November 9, 2010. Accepted April 6, 2011

Published online October 6, 2011. 